RESIDENT

\& FELLOW

SECTION

Section Editor

Mitchell S.V. Elkind,

MD, MS

Piero Verro, MS, MD

Address correspondence and reprint requests to Dr. Piero Verro, University of CaliforniaDavis Medical Center, 2315 Stockton Boulevard, Room 5308, Sacramento, CA 95825

piero.verro@ucdmc.ucdavis.edu

\section{Teaching NeuroImages: \\ Brain air embolism due to YAG \\ laser bronchoscopy}
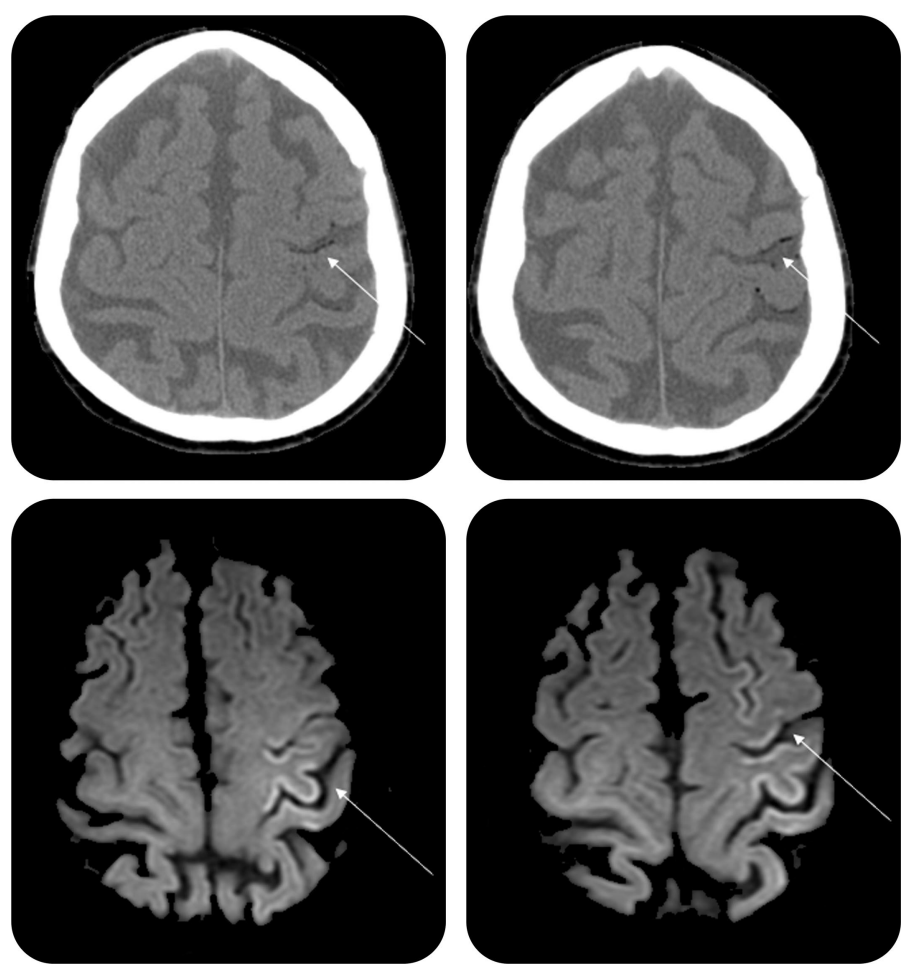

An 83-year-old man with renal cell carcinoma with lung metastases was admitted with hemorrhage from an endobronchial tumor. He underwent bronchoscopy, and an Nd-YAG laser was used to debulk the tumor. Immediately after, the patient was unarousable with left eye deviation and right arm plegia. Head CT showed air embolism in distal branches of the left middle cerebral artery (figure). MRI showed diffusion-weighted changes consistent with acute infarction (figure).

Air embolism is a rare complication of bronchial laser ablation: it is thought to result from laser tip contact with bronchial tissue as cooling gas is forced into exposed and bleeding pulmonary vessels which have been eroded by the tumor. ${ }^{1}$ Air bubbles then embolize to the brain. An alternative theory is that high local air pressure is created when the bronchoscope occludes a small distal bronchus, impeding the escape of cooling air, with resulting entrapment of air in pulmonary vessels.

Hyperbaric therapy can be an effective treatment for brain air embolism. ${ }^{2}$ In the present case, this therapy was declined.

\section{REFERENCES}

1. Tellides G, Ugurlu B, Kim R, Hammond G. Pathogenesis of systemic air embolism during bronchoscopic Nd:YAG laser operations. Ann Thorac Surg 1998;65:930-934.

2. Blanc P, Boussuges A, Henriette K, Sainty JM, Deleflie M. Iatrogenic cerebral air embolism: the importance of an early hyperbaric oxygenation. Intensive Care Med 2002;28:559563. 


\title{
Neurology
}

\author{
Teaching NeuroImages: Brain air embolism due to YAG laser bronchoscopy \\ Piero Verro \\ Neurology 2010;75;e73 \\ DOI 10.1212/WNL.0b013e3181fb4452
}

\section{This information is current as of November 1,2010}

Updated Information \&

Services

References

Subspecialty Collections

Permissions \& Licensing

Reprints including high resolution figures, can be found at: http://n.neurology.org/content/75/18/e73.full

This article cites 2 articles, 0 of which you can access for free at: http://n.neurology.org/content/75/18/e73.full\#ref-list-1

This article, along with others on similar topics, appears in the following collection(s):

All Cerebrovascular disease/Stroke

http://n.neurology.org/cgi/collection/all_cerebrovascular_disease_strok $\mathrm{e}$

Embolism

http://n.neurology.org/cgi/collection/embolism

Other cerebrovascular disease/ Stroke

http://n.neurology.org/cgi/collection/other_cerebrovascular_disease_st roke

Information about reproducing this article in parts (figures,tables) or in its entirety can be found online at:

http://www.neurology.org/about/about_the_journal\#permissions

Information about ordering reprints can be found online:

http://n.neurology.org/subscribers/advertise

Neurology ${ }^{\circledR}$ is the official journal of the American Academy of Neurology. Published continuously since 1951, it is now a weekly with 48 issues per year. Copyright Copyright (? 2010 by AAN Enterprises, Inc.. All rights reserved. Print ISSN: 0028-3878. Online ISSN: 1526-632X.

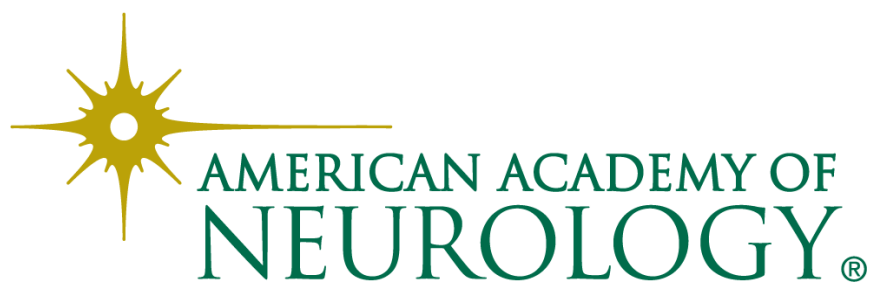

